Józef Pochwat MS ${ }^{1}$

0000-0003-4952-6137

Międzyzakonne Formacyjne Studium Teologiczne w Krakowie

\title{
Wybrane aspekty
}

z przepowiadania św. Cezarego z Arles.

Czy św. Cezary z Arles

będzie nowym doktorem Kościoła?

Cezary z Arles urodził się w 470 roku w Cabillonensis, obecnie Chalon-sur-Saône, prawdopodobnie w rodzinie o rzymskim rodowodzie i już chrześcijańskiej. Młodość spędził w klasztorze na jednej z wysp Leryńskich ${ }^{2}$, następnie, z powodu słabego stanu zdrowia, udał się do Arles. Tam otrzymał święcenia kapłańskie, a biskup Arles Eoniusz, widząc jego

1 Józef Pochwat MS - ur. w 1960 roku, kapłan od 1986 roku, dr hab., absolwent patrologii w Instytucie Teologii Dogmatycznej na Wydziale Teologicznym Uniwersytetu Papieskiego Jana Pawła II w Krakowie. Autor publikacji naukowych, popularnonaukowych, tłumacz, wykładowca, kapelan Sióstr Matki Bożej Miłosierdzia w Sanktuarium Bożego Miłosierdzia w Krakowie-Łagiewnikach. Ostatnio wydał: La Salette w świetle dokumentów źródłowych i magisterium Kościoła, Kraków 2016; Kościót św. Faustyny, Kraków 2016; Maryja i święci w pismach św. Faustyny, Kraków 2017; Pelagiusz, Pisma, Kraków 2017; Sulpicjusz Sewer, Kroniki, Kraków 2017 (Źródła Monastyczne, 79); Spowiedź i kierownictwo duchowe w pismach św. Faustyny, Kraków 2018; Pelagiusz, Komentarz do Listów św. Pawła, Kraków 2019. Email: jotpe67@wp.pl.

2 Wyspy Leryńskie (Îles de Lérins), archipelag czterech wysp położony na Morzu Liguryjskim. 
zapał duszpasterski i wykształcenie, wyznaczył go na swojego następcę. $\mathrm{Na}$ tym stanowisku pozostał Cezary czterdzieści lat, od 503 r. do swojej śmierci około 543 roku. Cezary założył klasztor pw. św. Jana. Osobiście starał się w Rawennie u króla Teodoryka o wykupienie mieszkańców Orange wziętych do niewoli i rozmawiał z papieżem Symmachem. Papież ustanowił Arles metropolią kościelną, a w roku 514 podniósł je do godności prymasostwa Galii. Biskup Cezary odbył aż 6 synodów (Agde 506, Arles 524, Carpentras 527, Orange 529, Vaison 529, Marseille 533), był świetnym organizatorem życia kościelnego ${ }^{3}$.

Cezary, jako gorliwy duszpasterz niestrudzenie głosił kazania, których do dzisiaj zachowało się 238. Napisał trzy, skromnych raczej rozmiarów, traktaty teologiczne: De Mysterio Sanctae Trinitatis, Breviarium adversus haereticos, De gratia ${ }^{4}$. Zarówno kazania, jak i traktaty oraz Expositio in Apocalypsim ${ }^{5}$ zawierają zasadniczo odpowiedzi na problemy, jakimi żyli chrześcijanie w pierwszej połowie VI wieku w Galii ${ }^{6}$.

3 Odnośnie do danych biograficznych św. Cezarego z Arles zob. np.: M.-J. Delage, Introduction, w: Césaire d'Arles, Sermons au peuple, SCh 175, Paris 1971, s. 13-214; Antoni Żurek, Cezary z Arles, Kraków 2003; Józef Pochwat MS, Sprawiedliwość i miłosierdzie. Studium „Kazań do ludu" św. Cezarego z Arles, Kraków 2008, s. 7-24; Cyprian, Firmin, Wiwencjusz, Messjan, Stefan, Żywot Cezarego z Arles, przeł. A. Strzelecka, opr. P. Wygralak, POK 32, Poznań 2008; J. Pochwat MS, Św. Cezary z Arles i jego czasy, w: Św. Cezary z Arles, Kazania do ludu, przekł. kazań 1-55 (S. Ryznar CSsR), przekł. kazań 56-80 (J. Pochwat MS), Kraków 2011, s. 7-32 (ŹMT, 57).

4 Cezary z Arles, Pisma dogmatyczne i egzegetyczne, przeł. A. Strzelecka, opr. P. Wygralak, Poznań 2004 (Pisma Ojców Kościoła [dalej: POK], 29).

5 Cezary z Arles, Homilie do Księgi Rodzaju. Objaśnienie Apokalipsy św. Jana, oprac. A. Żurek, Kraków 2002, s. 85-167 (Biblioteka Ojców Kościoła [dalej: BOK], 17); Cezary z Arles, Pisma dogmatyczne i egzegetyczne, przeł. A. Strzelecka, opr. P. Wygralak, Poznań 2004, s. 93-191 (POK, 29).

6 Por. J. Pochwat MS, Obraz społeczeństwa Galii pierwszej połowy VI wieku. Studium „Kazań doludu" św. Cezarego z Arles, w: Fructus Spiritus est Caritas: Księga jubileuszowa ofiarowana Księdzu Profesorowi Franciszkowi Drączkowskiemu z okazji siedemdziesiątej rocznicy urodzin, czterdziestopięciolecia święceń kapłańskich i trzydziestopięciolecia pracy naukowej, red. M. Wysocki, Lublin 2011, s. 315-333; J. Pochwat MS, Św. Cezary z Arles i jego czasy, w: Św. Cezary z Arles. Kazania do ludu (1-80), tłum. S. Ryznar CSsR (1-55), J. Pochwat MS (56-80), Kraków 2011, s. 5-21 (ŹMT, 57), bibliografia, s. 23-32; J. Pochwat MS, Św. Cezary z Arles, jako nauczyciel modlitwy, na podstawie jego „Kazań do ludu”, w: Przez Maryję ku Wcielonemu Słowu, red. J. Kręcidło, Kraków 2012, s. 73-97 (Studia Salettensia, 5); J. Pochwat MS, Dzień Pański w nauczaniu św. Cezarego z Arles w świetle jego „Kazań do ludu”, „Vox Patrum” (dalej: VoxP) 33/60 (2013), s. 245-262; J. Pochwat MS, 
Artykuł ten jest owocem studiów dotyczących niektórych aspektów nauczania biskupa z Arles. Ma pomóc w odkryciu bogactwa jego doktryny i rzucić światło na zasadność ewentualnego zaliczenia św. Cezarego z Arles w poczet doktorów Kościoła. Czynię to, opierając się na studiach, które dotyczą 80 jego kazań, opublikowanych w serii wydawniczej Sources Chrétiennes (dalej: SCh) pod tytułem Sermons au peuple. Poniżej prezentuję streszczenia poszukiwań i odkryć, które ujmuję w ośmiu punktach. Punkt dziewiąty to przedstawienie dorobku polskich autorów dotyczących osoby i nauczania św. Cezarego z Arles.

1. Spotkanie ze św. Cezarym z Arles należało rozpocząć od przetłumaczenia jego kazań zatytułowanych Kazania do ludu. Pięćdziesiąt pięć z osiemdziesięciu kazań z tej grupy było już przetłumaczonych na język polski przed 2011 rokiem. Podjąłem przekład kazań od 56 do 80. Tłumaczenie to z rewizją 55 kazań ukazało się w serii Źródła Myśli Teologicznej (dalej: ŹMT) wydawanej przez księży jezuitów. Chodzi o: Św. Cezary z Arles, Kazania do ludu (1-80), tłum. Stefan Ryznar CSsR (1-55) i Józef Pochwat MS (56-80). Wstęp: Św. Cezary z Arles ijego czasy oraz bibliografia: Józef Pochwat MS, Kraków 2011 (ŹMT, 57). Źródłem i podstawą tłumaczenia było: Cesaire d'Arles, Sermons au peuple, introduction, traduction et notes par M.-J. Delage, por. przypis 6.

2. Tłumaczenie i studium kazań zaowocowało pozycją pt. Sprawiedliwość i miłosierdzie. Studium „Kazań do ludu” św. Cezarego z Arles. Rozdział piąty tej pracy stanowi obszerne podsumowanie zagadnienia podjętego w tytule książki. Ograniczę się do przedstawienia zasadniczego

Konsekwencje chrztu według św. Cezarego z Arles, w: Chrzest w teologicznej refleksji Ojców Kościoła, Poznań 2016, s. 77-94 (Teologia Patrystyczna [dalej: TPatr], 13); J. Pochwat MS, Konsekwencje chrztu według św. Cezarego z Arles, w: Chrzest w teologicznej refleksji Ojców Kościoła, Poznań 2016, s. 77-94 (TPatr, 13); J. Pochwat MS, Specyfika głównych ośrodków życia monastycznego w Galii w IV i V wieku, „Polonia Sacra” 21 (2017) nr 3 (48), s. 107-128; J. Pochwat MS, Sprawiedliwość Boga wobec Szatana na podstawie jedenastego kazania do ludu św. Cezarego z Arles, „Polonia Sacra” 21 (2017) nr 4 (49), s. 167-185.

7 Césaire a'Arles, Sermons au peuple, introductions, traduction et notes par M.-J. Delage, t. 1, Paris 1971 (SCh, 175); t. 2, Paris 1978 (SCh, 243); t. 3, Paris 1986 (SCh, 330). 
wniosku o istnieniu, zdaniem św. Cezarego z Arles, organicznego związku sprawiedliwości z miłosierdziem.

Sedno swojej nauki na temat sprawiedliwości i miłosierdzia przedstawił autor w kazaniu jedenastym, w którym bronił sprawiedliwości Boga jako podstawy wszystkich Jego przymiotów. W tym kazaniu jakby przez mgłę ogląda razem ze słuchaczami szczyt przymiotów, czyli miłość Boga. Połączenie zaś sprawiedliwości z tą miłością wiedzie przez miłosierdzie.

Cezary ukazuje, jak bardzo Bóg szanuje wolność swoich stworzeń i liczy się z prawami tej wolności. To w imię sprawiedliwości szanuje prawa szatana, który podstępnie uczynił człowieka swoim niewolnikiem. Bóg nie mogąc w imię sprawiedliwości odwołać się do wszechmocy, by pokonać szatana, zastosował wobec niego podstęp, czyli ten sposób, jaki on wybrał i sprawił, że szatan stał się winnym zbrodni zabicia Chrystusa. Tę taktykę Syna Bożego autor odczytuje w kategoriach sprawiedliwości. Skoro szatan posłużył się podstępem, po sprawiedliwości również podstępem Syn Boga mógł odebrać mu łup.

To dogmatyczne rozważanie na temat metody odkupienia stanowi dla Cezarego fundament refleksji głównie moralnej, w której sprawiedliwość przeplata się z miłosierdziem. Sprawiedliwość i miłosierdzie Boga są dla niego wzorcowym modelem sprawiedliwości ludzkiej i ludzkiego miłosierdzia, które człowiek wciąż musi w sobie doskonalić.

Sprawiedliwość traktuje autor jako rodzaj daru wyjściowego i zarazem początek chrześcijańskiego życia. Miłosierdzie natomiast - jako konsekwencję budowania życia na tym fundamencie. Stąd też można powiedzieć, że sprawiedliwość jest wymogiem miłosierdzia w życiu chrześcijanina, a miłosierdzie zawsze łączy się z darem sprawiedliwości. Rozdzielenie tych wartości powoduje ich zniekształcenie. Sprawiedliwość bez miłosierdzia może łatwo przerodzić się w bezduszny rygoryzm, natomiast miłosierdzie bez sprawiedliwości może stać się niesprawiedliwością i krzywdą dla wielu. Z tymi problemami nasz autor spotkał się w Arles, bowiem zarówno on, jak i jego wierni znali z autopsji niesprawiedliwość, a nawet okrucieństwo ${ }^{8}$.

8 Por. Sermo 70, 2, Paris 1986 (SCh, 330), s. 164; Kaz. 70, 2, Kraków 2011, s. 374-376 (ŹMT, 57). 
W kazaniach Cezarego częściej dochodzi do głosu sprawiedliwość, kiedy na różne sposoby chce uświadomić słuchaczom, że sam Bóg otworzył ludziom bramę do nieba na zasadzie sprawiedliwej nagrody za miłosierdzie okazane ludziom na ziemi przez przebaczenie, jak i przez czyny miłości. Miłosierdzie Boga po sprawiedliwości jest ofiarowane wszystkim ludziom.

Refleksja kaznodziei nad sprawiedliwością i miłosierdziem Boga uczy przede wszystkim wchodzenia w głąb tajemnic objawienia, zawartych w Piśmie Świętym. Opanowanie tej umiejętności jest dla niego ważniejsze niż sam konkretny wykład tekstu, który podaje. Cezaremu zależy na tym, aby słuchacze sami umieli coraz bardziej zgłębiać tekst natchniony i dzięki niemu zbliżali się do Boga żywego.

Studium analityczne Kazań do ludu św. Cezarego z Arles zmusza do głębszej refleksji nad dowartościowaniem, również we współczesnym nauczaniu, problematyki sprawiedliwości i miłosierdzia. Dzisiaj bowiem obserwujemy ludzi, także będących w Kościele, którzy chcą jedynie odwoływać się do miłosierdzia, pomijając nierozerwalnie z nim związaną sprawiedliwość. Czynią to najczęściej zapominając o najważniejszym źródle mądrości - natchnionym tekście Biblii. Kto wie, czy krytyka ze strony współczesnych nam ludzi oraz odwracanie się od Kościoła, szczególnie młodych osób, nie mają swojego głównego źródła w niedowartościowaniu połączenia sprawiedliwości z miłosierdziem.

Warto oddać głos św. Cezaremu, który powiedział:

Ponieważ Bóg jest nie tylko miłosierny, ale i sprawiedliwy, wierzymy w oba Jego przymioty: bojąc się sprawiedliwości wierzymy w miłosierdzie, ale też nie kochajmy tak miłosierdzia, żebyśmy nie myśleli o sprawiedliwości. Nie wolno ani źle nadziei pokładać, ani z powodu zła nadziei tracić. źle ufa, kto bez pokuty i bez dobrych uczynków sądzi, że dostąpi miłosierdzia. I źle rozpacza, kto po dobrych uczynkach nie wierzy, że dostąpi miłosierdzia9.

W związku z tym, że zakres badań tej pracy został ograniczony tylko do Kazań do ludu, czyli pierwszych osiemdziesięciu z dwustu trzydziestu ośmiu kazań zachowanych z całego bogatego dorobku tego kaznodziei, mam świadomość, że ten dyskurs nie stanowi jeszcze pełnej syntezy

9 Kazania... 12, 5, dz. cyt., s. 106 (ŹMT, 57). 
nauki o sprawiedliwości i miłosierdziu w całym nauczaniu św. Cezarego z Arles. Istnieje więc uzasadniona potrzeba studiów nad tym tematem zarówno na podstawie innych dzieł Cezarego, jak i dzieł współczesnych mu autorów.

3. Święty Cezary, aby ukazać swoim słuchaczom miłosierdzie Boga w aspekcie eschatologicznym, koncentruje się na tekstach Nowego Testamentu. Jako doświadczony duszpasterz poucza swoich słuchaczy o konieczności okazywania miłosierdzia innym, bowiem droga do Bożego miłosierdzia prowadzi przez ziemskie. Zapłatą za miłosierdzie okazane potrzebującym na ziemi jest otrzymanie miłosierdzia od Boga.

Kaznodzieja podkreśla wagę odpowiedzialności chrześcijanina, przypomina prawdę o sądzie i konsekwentnie przedstawia prawdę o Bożej nagrodzie i karze. Wzorem dla miłosierdzia człowieka jest, zdaniem Cezarego, miłosierdzie Boga.

Na podstawie przeprowadzonej analizy trudno jednoznacznie odpowiedzieć na pytanie, czy Cezary mówiąc o sądzie ma na myśli sąd szczegółowy czy ogólny. Podobnie sądzi M.-J. Delage ${ }^{10}$, mówiąc że: „Nie tylko Augustyn i inni Ojcowie Starożytni, ale i Cezary nie czyni w swych kazaniach wyraźnego rozróżnienia pomiędzy sądem osobistym po śmierci a Sądem Ostatecznym"11. Trzeba jednak zaznaczyć, że opisy sądu częściej mają wymiar indywidualny, a nie odwołują się do społeczności zbawionych i potępionych.

Człowiek, jak podkreśla biskup Arles, ma możliwość praktykowania miłosierdzia tylko w życiu doczesnym. W momencie sądu kończy się czas miłosierdzia, który należało okazywać ludziom potrzebującym, w których zawsze ukrywa się Chrystus. Miłosierdzie zatem jest związane z czasem, bowiem w momencie śmierci pozostaje sprawiedliwość Boża, która

10 „Pas plus qu'Augustin et les autres Pères de l'Antiquité, Césaire ne fait, dans sa prédication, de distinction explicite entre le jugement personnel après la mort et le Jugement dernier" - Sermo 56, przypis 1, s. 12-13 (SCh, 330).

11 Innego zdania jest A. Eckmann wykazując, że: „Biskup Hippony odróżnia kary doczesne po śmierci (poenae temporariae post mortem) od kar wiecznych (poenae sempiternae)", por. A. Eckmann, Grzech pierworodny jako źródło cierpień człowieka u św. Augustyna, w: Grzech pierworodny, Kraków 1999, s. 109-125, szczególnie s. 116 (ŹMT, 12). 
rozstrzygnie, czy ludzkie czyny zasługują na Jego miłosierdzie. Dlatego św. Cezary stawia swoim słuchaczom za wzór Boga, który chce, aby człowiek był miłosierny dla ubogiego według wzoru Bożej litości nad nim samym.

Zważywszy na fakt, że zakres badań w niniejszym artykule został ograniczony do Kazań do ludu, mam świadomość, że nie stanowi on jeszcze pełnej syntezy nauki o Nowotestamentalnym wymiarze eschatologii w całym nauczaniu św. Cezarego z Arles. Istnieje więc dalsza potrzeba studiów nad tym tematem uwzględniająca zarówno inne dzieła Cezarego, jak i dzieła współczesnych mu autorów ${ }^{12}$.

4. Św. Ceazary z Arles w swoich kazaniach pozostawił obraz społeczeństwa Galii z przełomu V i VI wieku. Należy zwrócić uwagę na fakt, że św. Cezary nie przyjmuje postawy wrogiej wobec religii czy wierzeń pogańskich (obojętnie czy pochodzących z Galii, Imperium Rzymskiego czy od barbarzyńców). Nawołuje chrześcijan do odcięcia się od zwyczajów i wierzeń pogan. Cezary posługuje się tekstami zarówno ze Starego, jak i Nowego Testamentu, aby przedstawić przykłady i zachęty w nich zawarte, jako czytelne wskazania dla wyznawców Chrystusa.

Z badanego przez nas materiału źródłowego wynika, że obyczaje, sposób życia zakorzeniony w ludzkiej świadomości (i podświadomości) pozostają aktualne, pomimo wymagań religii chrześcijańskiej. Na tym polu dochodzi do zderzenia i napięć. Konflikt jest nie do uniknięcia, a jak pokazuje doświadczenie, szala zwycięstwa wydaje się przechylać na stronę obyczajów pogańskich. Chrześcijaństwu pozostaje zatem zaadaptowanie i zmodyfikowanie, odpowiednio do swoich potrzeb, dawnej obyczajowości. Chrześcijaństwo przyjęło wiele elementów obyczajowości pogańskiej, co wiązało się z długotrwałym procesem przyjmowania nowych wyznawców ze środowisk pogańskich. Analiza tekstów Kazań do ludu św. Cezarego z Arles pokazuje, że przeciętny chrześcijanin Galii z pierwszej połowy VI wieku niekoniecznie rezygnował z dawnych

12 J. Pochwat MS, Nowotestamentalny wymiar eschatologii. Studium „Kazań do ludu” św. Cezarego z Arles, w: Problemy duszpasterskie starożytnego Kościoła, Lublin 2009, s. 223-237. 
obyczajów, często stojących w diametralnej sprzeczności z wymaganiami religii chrześcijańskiej.

Wezwania Cezarego do zaniechania praktyk kultów pogańskich, pijaństwa, przestrzegania zasad moralnych szczególnie w dziedzinie seksualnej, zaniechania praktyk aborcyjnych i stosowania środków antykoncepcyjnych, dbania o odpowiedzialność za wypowiadane słowa, umiar w korzystaniu z uczt i rozrywek, posługiwania się uczciwym wymiarem sprawiedliwości niezależnie od statusu społecznego jednostki, pozostawały niejednokrotnie w sferze pobożnych życzeń.

Próba zasiania w życiu codziennym społeczeństwa Galii pierwszej połowy VI wieku chrześcijańskich wzorców postępowania w wielu przypadkach kończyła się niepowodzeniem. Wydaje się, że chrześcijaństwo na tym polu pozostało bezsilne, niedostatecznie zrozumiałe i dokonał się tryumf obyczajowości pogańskiej (ludów Galii, czy ludności barbarzyńskiej). Obyczajowość pogańska zwalczana przez Cezarego (wróżby, gusła, zabobony, amulety, czary, astrologia, aborcja, środki antykoncepcyjne, pijaństwo, uczty, hazard itp.), w niektórych przypadkach, w takiej samej lub nieco zmienionej formie, przeniknęła do kultury chrześcijańskiej ${ }^{13}$.

5. Cezary, mówiąc o modlitwie, określa ją jako duchową jałmużnę, która oczyszcza z grzechów i prowadzi człowieka do świętości. Podkreśla jej duchowy wymiar i związek z Komunią św. Zwraca uwagę szczególnie na Modlitwę Pańską i wstawienniczą. Podaje warunki dobrej modlitwy: poznanie prawa Bożego, skupienie, dostosowanie woli modlącego się z wolą Bożą. Ukazuje znaczenie postawy na modlitwie, dając za wzór przykład Jezusa i świętych. Jako doświadczony duszpasterz przestrzega przed przeszkodami, które mogą stawać człowiekowi na drodze do praktykowania dobrej modlitwy: roztargnienia, złe myśli, szatan, złe zachowanie w kościele, a także zwrócenie się do praktyk kultu pogańskiego. Cezary

13 J. Pochwat MS, Obraz społeczeństwa Galii pierwszej połowy VI wieku. Studium „Kazań doludu" św. Cezarego z Arles, w: Fructus Spiritus est Caritas: Księgajubileuszowa ofiarowana Księdzu Profesorowi Franciszkowi Drączkowskiemu z okazji siedemdziesiątej rocznicy urodzin, czterdziestopięciolecia święceń kapłańskich i trzydziestopięciolecia pracy naukowej, red. M. Wysocki, Lublin 2011. 
ubolewa nad brakiem modlitwy i przypomina rodzicom o obowiązku uczenia dzieci rozmowy z Bogiem.

Przy takim podejściu do modlitwy, Cezary jawi się jako doświadczony duszpasterz i znawca przedmiotu. Jego podejście do modlitwy ma charakter praktyczny, ukazuje jej wartość i konkretne konsekwencje w życiu człowieka $^{14}$.

6. Cezary uświadamia swoim diecezjanom wagę dnia Pańskiego i dni świątecznych. Uczęszczanie do kościoła ma wymiar społeczny, odróżnia w sposób jednoznaczny wyznawców Chrystusa od pogan. Biskupowi Arles zależy na tym, aby chrześcijanie systematycznie i regularnie uczęszczali na nabożeństwa do kościoła, by dbali o punktualność i nie wychodzili ze świątyni przed zakończeniem Mszy św. Cezary jako doświadczony duszpasterz zwraca wiernym uwagę na ich postawę w kościele. Za wzór daje ewangelicznego celnika, który był uniżony przed Bogiem zarówno ciałem (skłon), jak i duchem (pokora serca). Zachowanie w kościele jest wyrazem wiary lub jej zaprzeczeniem, dlatego biskup Arles przypomina o godnym zachowaniu, domagając się w świątyni ciszy. Zwraca także uwagę na ubiór przychodzących do kościoła. Wierny musi mieć świadomość, że w czasie Mszy św. spotyka się z Bogiem i dlatego ma zadbać o czystość swego sumienia i czystość ubrania.

Cezary pokazuje różnicę pomiędzy chrześcijaństwem i pogaństwem. Chrześcijanie świętują niedzielę, poganie czwartek na cześć bóstwa Jowisza. Domaga się od wiernych zaniechania prowadzenia spraw sądowych w niedzielę i powstrzymania od wykonywania pracy. Podkreśla natomiast potrzebę pełnienia dobrych uczynków wobec bliźnich, szczególnie jałmużny oraz poświęcania dużej ilości czasu na czytanie słowa Bożego.

Biskup Arles w centrum dnia Pańskiego stawia Eucharystię. Wierni mają przynosić do kościoła dary do konsekracji, które później są rozdzielane wszystkim. Poucza, że Eucharystia jest prawdziwym Ciałem i Krwią

14 J. Pochwat MS, Św. Cezary z Arles, jako nauczyciel modlitwy, na podstawie jego „Kazań do ludu", w: Przez Maryję ku Wcielonemu Słowu, red. J. Kręcidło MS, Kraków 2012, s. 73-97 (Studia Salettensia, 5). 
Chrystusa. Wykazuje, że Komunia św. jest lekarstwem dla człowieka - dla jego ciała i dla jego duszy. Stąd jego troska, aby wierni przyjmowali Eucharystię z czystym sercem. Naucza, że małżonkowie przed przystąpieniem do Komunii św. mają zachować przynajmniej na trzy dni przed Jej przyjęciem wstrzemięźliwość seksualną. Cezary uważa, że niewierność Chrystusowi jest zwróceniem serca ku szatanowi, co uniemożliwia przystępowanie do stołu Pańskiego. Koniecznym warunkiem, by móc przyjąć Eucharystię, jest przebaczenie bliźniemu ${ }^{15}$.

7. Cezary z Arles i jego spojrzenie na konsekwencje chrztu świętego. Należy stwierdzić, że św. Cezary z Arles nie pisał o teologii chrztu, że jest to wejście w świat Trójcy Świętej, że przez chrzest człowiek staje się przybranym dzieckiem Bożym i członkiem wspólnoty Kościoła. Biskupa z Arles interesuje nie tyle teoretyczne rozważanie doniosłości chrztu świętego, co praktyczne skutki tegoż w codziennym życiu chrześcijanina. Chrzest bowiem ma się wyrażać w wyznawanej wierze, która nie jest uczuciem i pobożnym pragnieniem, ale konkretnym czynem. Dopóki człowiek wypełnia czyny może mówić, że jest wierzącym. W tym rozumowaniu Biskup Arles opiera się głównie na Liście św. Jakuba i powtarza za nim, że „wiara bez uczynków jest martwa” (Jk 2, 26).

Święty Cezary z Arles uświadamiał swoim słuchaczy, że chrzest dokonuje odrodzenia człowieka i jest jego osobistą decyzją. W przypadku niemowląt i dzieci, rodzice biorą odpowiedzialność za przekaz wiary, który ma się spełniać w słowie i czynie. Najważniejszą rzeczą, jaka dokonuje się w chrzcie jest wyrzeczenie się diabła i jego przepychu. Przypomina zatem swoim parafianom, co znaczy wyrzec się szatana i jednocześnie odróżniać się od pogan, którzy żyją w zasięgu jego oddziaływania. Tym, co odróżnia chrześcijan od pogan, jest modlitwa ${ }^{16}$, uczestnictwo

15 J. Pochwat MS, Dzień Pański w nauczaniu św. Cezarego z Arles w świetle jego „Kazań do ludu", dz. cyt., s. 245-262.

16 Na temat modlitwy u św. Cezarego, zob. P. Wygralak, Praktyki pokutne w nauczaniu św. Cezarego z Arles, „Poznańskie Studia Teologiczne” 8 (1998), 104-105; J. Pochwat MS, Św. Cezary z Arles, jako nauczyciel modlitwy, na podstawie jego „Kazań do ludu”, w: Przez Maryje ku Wcielonemu Słowu, red. J. Kręcidło MS, Kraków 2012, s. 73-97 (Studia Salettensia, 5). 
w niedzielnej i powszedniej Mszy świętej ${ }^{17}$. Chrześcijanin świętuje niedzielę nie tylko poprzez uczestnictwo w Eucharystii, ale też powstrzymuje się od pracy, nie bierze udziału w widowiskach i nie uczęszcza do sądu. Oprócz tego ochrzczony w odróżnieniu od poganina nie może zajmować się magią i wróżbiarstwem, noszeniem amuletów, upijać się, brać łapówki, niesprawiedliwie sprawować sądy itp.

Dla Biskupa z Arles niespełnianie wymogów wiary sprawia, że człowiek, pomimo przyjęcia chrztu, staje się naśladowcą demonów, które wierzą, że Bóg jest, ale nie czynią Jego woli. Dla tych, którzy grzeszą, przewidziana jest pokuta oraz dawanie jałmużny i miłość nieprzyjaciół dla zmazania grzechów. Wiara otwiera perspektywę nagrody życia wiecznego, ale należy się liczyć z tym, że odejście od niej może być związane z konsekwencją kary wiecznej.

Święty Cezary z mocą przypominał, że samo powstrzymanie się od grzechu jeszcze nie wystarcza. Chrześcijanin ma nie tylko unikać zła, ale czynić dobro, wówczas jego wiara się rozwija i przynosi oczekiwane owoce. Ochrzczony ma się odróżniać od poganina sposobem życia i postępowania, w sposób jasny i czytelny dla każdego człowieka ${ }^{18}$.

8. Cezary z Arles (†543) w jedenastym kazaniu do ludu dokonał precyzyjnego omówienia zagadnienia dotyczącego sprawiedliwości Boga wobec szatana. W tym kazaniu dał tak wyczerpujące wyjaśnienie na ten temat, że jest ono swoistego rodzaju traktatem teologicznym. Bóg, jak zauważa, mógł użyć wobec szatana swojej wszechmocy, nie uczynił jednak tego, ponieważ nie chciał naruszyć sprawiedliwości. Bóg jest sprawiedliwy zarówno wobec szatana, jak i wobec człowieka. Cezary wyjaśnił, że szatan sam siebie zgubił, nikt go do tego nie zmusił, a powodem była zazdrość. $Z$ kolei szatan, jak zauważył Cezary, z zazdrości doradził człowiekowi wybór zła, nie zmusił człowieka do odwrócenia się od Boga, ponieważ człowiek był wolny. Człowiek

17 Na ten temat, zob.J. Pochwat MS, Dzień Pański w nauczaniu św. Cezarego z Arles wświetle jego „Kazań do ludu”, dz. cyt., s. 245-262.

18 J. Pochwat MS, Konsekwencje chrztu według św. Cezarego z Arles, w: Chrzest w teologicznej refleksji Ojców Kościoła, Poznań 2016, s. 77-94 (Teologia Patrystyczna, 13). 
natomiast, zamiast należeć do Boga, który go stworzył, wybrał propozycję szatana, która sprowadziła na niego śmierć. Cezary pokazał też dwa etapy wyrwania człowieka z niewoli szatana. Pierwszym było Wcielenie, czyli przyjście Chrystusa w ciele podobnym do ciała grzesznego, drugim był krzyż. Sprawiedliwy Chrystus przyjął na siebie niesprawiedliwość i ujawnił zbrodnicze i niesprawiedliwe postępowanie diabła. Szatan w Wielki Piątek, gdy zabił Chrystusa na krzyżu, przekroczył prawo sprawiedliwości. Dopuścił się zbrodni na Jezusie, stał się winny, gdyż skazał na śmierć całkowicie niewinną osobę. Szatan jako winny, musiał przeżyć konfiskatę tego, co zagarnął - człowieka. Chrystus, jak wykazał Cezary, uwolnił rodzaj ludzki spod władzy szatana przez swoją sprawiedliwość. Uczynił to nie jako Bóg, lecz w ludzkim ciele. Sprawiedliwość Chrystusa ujawnia Jego miłosierdzie względem człowieka.

W śmierci Jezusa Cezary dostrzega jedyną szansę na sprawiedliwość i wyrwanie się spod panowania diabła. Chrystus uwolnił rodzaj ludzki spod władzy szatana przez swoją sprawiedliwość. Współpraca z Chrystusem, który udziela wszelkich dobrodziejstw bez uprzednich zasług, dokonuje się dzięki Bożemu Miłosierdziu ${ }^{19}$.

Miłosierdzie Boże wobec człowieka przejawia się w złożeniu ofiary przebłagalnej za grzech. Składającym ofiarę jest Syn, ofiarą też Syn, Chrystus, sprawiedliwy i wolny od jakiegokolwiek grzechu. Cezary stwierdza, że na Golgocie szatan stał się winny i dlatego słusznie jest nazwany nieprzyjacielem. A jako winny, przeżywa konfiskatę swoich łupów.

Wyjaśnienie taktyki szatana i Jezusa, opartej o zasadę sprawiedliwości, było potrzebne Cezaremu do ukazania wielkości Bożego Miłosierdzia wobec człowieka. Szatan podstępem namówił człowieka, by był jego wspólnikiem, a wykorzystał do tego jego wolność. Bóg podstępem doprowadził szatana do zbrodni na Kalwarii i jako winnemu, po sprawiedliwości odebrał łup, tzn. człowieka. To uwolnienie jest dla człowieka

19 Na temat relacji sprawiedliwości i miłosierdzia w nauczaniu Cezarego, por. J. Pochwat MS, Sprawiedliwość i miłosierdzie. Studium „Kazań do ludu” św. Cezarego z Arles, Kraków 2008 . 
darem miłosierdzia, wysłużonym przez sprawiedliwego Chrystusa. Dar ten wzywa do współpracy z Bogiem w celu wykorzystania naszej wolności. Po zwycięstwie Jezusa nad szatanem - jesteśmy znów wolni należymy do Chrystusa, posiadamy wiedzę o metodach walki szatana z nami i metodach naszej walki z nim. Syn Człowieczy jest dla nas wzorem ${ }^{20}$.

9. Dorobek polskich autorów dotyczący spuścizny nauczania św. Cezarego z Arles. Ograniczam się do zasygnalizowania najważniejszych publikacji w języku polskim ${ }^{21}$. Z podręczników na szczególną uwagę zasługują prace takich autorów, jak: Berthold Altaner ${ }^{22}$, Marian Banaszak ${ }^{23}$, Karl Bihlmeyer ${ }^{24}$, Andrzej Bober ${ }^{25}$, Henry Chadwick $^{26}$, Maria Cytowska ${ }^{27}$, Jean Daniélou ${ }^{28}$, Jacques Fontaine ${ }^{29}$, Ludwik Gładyszewski ${ }^{30}$, Bolesław Kumor ${ }^{31}$, Henri-Irénée Marrou ${ }^{32}$, Henryk

20 Więcej na ten temat, por. J. Pochwat MS, Sprawiedliwość Boga wobec Szatana na podstawie jedenastego kazania do ludu św. Cezarego z Arles, „Polonia Sacra” 21 (2017) nr 4 (49), s. $167-185$.

21 Literaturę obcojęzyczną omówiłem w: J. Pochwat MS, Sprawiedliwość i miłosierdzie. Studium „Kazań do ludu” św. Cezarego z Arles, Kraków 2008, s. 18-21.

22 B. Altaner, A. Stuiber, Patrologia, przeł. P. Pachciarek, Warszawa 1990, s. 618-619, uwagę zwraca tu bogata bibliografia.

23 M. Banaszak, A. Weiss, Arles, w: Encyklopedia katolicka, t. 1, Lublin 1989, s. 926.

${ }^{24}$ K. Bihlmeyer, H. Tüchle, Historia Kościoła, t. 1, tłum. J. Klenowski, Warszawa 1971, s. 422 .

25 A. Bober, Antologia patrystyczna, Kraków 1965, 399-412; A. Bober, Antologia patrystyczna, Kraków 1965, s. 399-412.

26 H. Chadwick, Kościół w epoce wczesnego chrześcijaństwa, tłum. A. Wypustek, Warszawa 2004, s. 246-256.

${ }_{27}$ M. Cytowska, H. Szelest, Literatura Rzymska. Okres cesarstwa. Autorzy chrześcijańscy, Warszawa 1994, s. 244-275; 283-285.

28 J. Daniélou, H.-I. Marrou, Historia Kościoła, tłum. M. Tarnowska, t. 1, Warszawa 1984, s. $303 ; 315 ; 319 ; 328$.

${ }^{29}$ J. Fontaine, La littérature latine chretiénne, Paris 1970; J. Fontaine, Chrześcijańska literatura łacińska. Rys historyczny, tłum. J. Słomka, Tarnów 1997, s. 160-162.

30 L. Gładyszewski, Cezary z Arles, w: Encyklopedia katolicka, t. 3, Lublin 1989, s. 42-44.

31 B. Kumor, Historia Kościoła, t. 1, Lublin 2001, s. 136, 188, 212.

32 H.-I. Marrou, Zmierzch Rzymu czy późna starożytność? III -VI wiek, tłum. M. Węcowski, Warszawa 1997, s. 122; 128-129. 
Pietras $^{33}$, Pierre Riché ${ }^{34}$, Marek Starowieyski ${ }^{35}$, Jan Maria Szymusiak ${ }^{36}$, Jan Śrutwa ${ }^{37}$, Antoni Żurek ${ }^{38}$.

Z opracowań na uwagę zasługują artykuły Żurka o małżeństwie i prokreacji $^{39}$, o katechezie ${ }^{40}$, o miłości chrześcijańskiej ${ }^{41}$, o formacji duchowieństwa ${ }^{42}$ i o wpływie św. Cezarego na miasto Arles ${ }^{43}$. O zadaniach biskupa pisze Roman Wiszniewski ${ }^{44}$, natomiast o przekazie wiary w środowisku wiejskim - Tadeusz Kołosowski ${ }^{45}$ i o kaznodziejstwie Cezarego - Grzegorz Jaśkiewicz ${ }^{46}$. Warte podkreślenia są informacje przekazane przez tego ostatniego na temat kultu świętych i nauce o szatanie w kazaniach św. Cezarego ${ }^{47}$. Spory dorobek w opracowaniu nauki kaznodziei mają: Jó-

33 H. Pietras, Dzień święty, Kraków 1992, s. 85; 107-109; 120-121.

34 P. Riché, Edukacja i kultura w Europie Zachodniej (VI-VIII w.), tł. M. Radożycka-Paoletti, Warszawa 1995, autor odwołuje się do Cezarego 45 razy; tenże, Education et culture dans l'occident barbare (VIe - VIIIe siècles), Paris 1962.

35 M. Starowieyski, Ze świata wczesnego chrześcijaństwa, Pelplin 1998, s. 134-136.

36 J.M. Szymusiak, Patrologia. Zagadnienia wybrane, Lublin 1971, s. 157.

37 J. Śrutwa, Galia, EK 5, Lublin 1989, s. 818-819.

38 A. Żurek, Wprowadzenie do Ojców Kościoła, Tarnów 1998, s. 224-225; A. Żurek, Pierwsze wieki Kościoła (I-VII), Tarnów 2000, s. 227; 232-234; 248-250; Św. Cezary z Arles, oprac. i wybór tekstów A. Żurek, Kraków 2002 (Ojcowie Żywi, 17); Św. Cezary z Arles, Homilie do Księgi Rodzaju, Objaśnienie Apokalipsy św. Jana, przeł., wstępem opatrzył i opr., A. Żurek, BOK 17, Kraków 2002; A. Żurek, Cezary z Arles, Kraków 2003.

39 A. Żurek, Il matrimonio nei Sermoni di Cesario di Arles, Roma 1985 (pr. dokt.); A. Żurek, Małżeństwo i prokreacja według Cezarego z Arles, VoxP 7 (1987) nr 12-13, s. 427-440.

40 A. Żurek, Katecheza Cezarego z Arles, VoxP 10 (1990) nr 18, s. 147-156.

${ }_{41}$ A. Żurek, La carità cristiana nella Gallia della fine del V e prima metà del VI secolo, „Studia Ephemeridis Augustinianum" 46 (1994), s. 567-572.

${ }_{42}$ A. Żurek, Formacja intelektualno-ascetyczna duchowieństwa $w$ V-VI wieku w Galii na podstawie pism św. Cezarego z Arles, VoxP 13-15 (1993-1995), nr 24-29, s. 173-180.

${ }_{43}$ A. Żurek, Wpływ św. Cezarego (†542/3 r.) na życie i ksztatt miasta Arles, w: Sympozja Kazimierskie Poświęcone Kulturze Świata Późnego Antyku i Wczesnego Chrześcijaństwa, pod red. B. Iwaszkiewicz-Wronikowskiej, D. Próchniaka, t. 3, Lublin 2002, s. 77-87.

44 R. Wiszniewski, Zadania biskupa w świetle „Kazań” św. Cezarego z Arles, VoxP 13-15 (1993-1995) nr 24-29, s. 181-202.

45 T. Kołosowski, Przepowiadanie wiary w środowisku wiejskim w kazaniach św. Cezarego z Arles, w: Ewangelizacja w epoce patrystycznej, red. F. Drączkowski, J. Pałucki, Lublin 1994, s. 39-60.

46 G. Jaśkiewicz, Problematyka moralna w kaznodziejstwie Cezarego z Arles, „Wrocławski Przegląd Teologiczny" 29 (2012), s. 97-107.

${ }_{47}$ T. Kołosowski, Nauczanie biskupa Cezarego z Arles na temat kultu świętych $w$ kontekście ówczesnej religijności chrześcijańskiej, „Saeculum Christianum” 6 (1999) nr 2, s. 5-16; 
zef Grzywaczewski ${ }^{48}$, Jarosław Piłat, który zestawił bibliografię dotyczącą św. Cezarego ${ }^{49}$ i Paweł Wygralak piszący o praktykach pokutnych i dobroci Boga w nauczaniu biskupa Arles ${ }^{50}$. Interesujące są myśli Emila Stanuli ${ }^{51}$, który w każdym niemal wstępie do przekładów dzieł Ojców Kościoła, rzuca światło na zawartość ich nauki. Należy również odnotować ciekawą pracę dotyczącą miłości jako zasady życia chrześcijańskiego, napisaną przez Leszka Durlaka ${ }^{52}$ na podstawie kazań Cezarego z Arles.

W języku polskim mieliśmy zaledwie kilka pozycji, które dotyczyły wprost miłosierdzia. O tym, że tematyką miłosierdzia w dziełach Ojców Kościoła zajmowano się w niewielkim zakresie, pisał czterdzieści sześć lat temu Bober ${ }^{53}$. Takiemu stanowi rzeczy pragnęło zaradzić środowisko krakowskich teologów ${ }^{54}$.

T. Kołosowski, Nauka o szatanie, jego oddziaływaniu na ludzi i walce z nim, w kazaniach św. Cezarego z Arles, w: Demonologia w nauce Ojców Kościoła, red. H. Pietras, Kraków 2000, s. 99-108 (ŹMT, 17).

48 J. Grzywaczewski, Pogłębianie wiedzy religijnejjako obowiazek chrześcijanina według Cezarego z Arles, „Roczniki Humanistyczne” 44 (1996), nr 3, s. 249-260; J. Grzywaczewski, Formacja permanentna duchowieństwa według św. Cezarego z Arles, w: Droga doskonalenia chrześcijańskiego w epoce patrystycznej, red. F. Drączkowski, J. Pałucki, M. Szram, Lublin 1997, s. 151-168; J. Grzywaczewski, La lecture à la campagne en Gaule au VIe siècle d'après les Sermons de Césaire d'Arles, VoxP 22 (2002), nr 42-43, s. 463-474; J. Grzywaczewski, The Biblical Idea of Divine Mercy in the Early Church, Warszawa 2016, s. 308-321.

49 J. Piłat, Św. Cezary z Arles (†543). Bibliografia-aktualny stan badań, w: Oblicza doskonałości chrześcijańskiej, red. M. Chmielewski, Lublin 1996, s. 206-218.

50 P. Wygralak, Praktyki pokutne wnauczaniu św. Cezarego z Arles, PozStTeol 8 (1998), s. 99 108; P. Wygralak, Grzech pierworodny w kaznodziejskim nauczaniu św. Cezarego z Arles (†542), w: Grzech pierworodny, tłum. ks. K. Obrycki, Kraków 1999, s. 131-140 (ŹMT, 12); P. Wygralak, Dobroć Boga Ojca w nauczaniu św. Cezarego z Arles, „Studia Aniquitatis Christianae” 15 (2001), 109-116; P. Wygralak, Cezarego z Arles wybrane kazania o pokucie i Bożym Miłosierdziu, 2004, s. 115-119 (TPatr, 1).

51 E. Stanula, Wstęp, w: Św. Cezary z Arles, Kazania, tłum., S. Ryznar, Warszawa 1989, s. 5-15 (PSP, 52).

52 L. Durlak, Miłość zasada życia chrześcijańskiego. Studium kazań Cezarego z Arles, Kraków 1998 (pr. lic.).

53 A. Bober, Miłosierdzie Boże w wypowiedziach Ojców Kościoła, w: Powołanie człowieka, t. 2, Poznań 1972, s. 41.

54 W zakresie teologii duchowości: J. Machniak, Doświadczenie Boga w tajemnicy Jego Miłosierdzia u bł. Siostry Faustyny Kowalskiej, Kraków 1999; P. Szweda MS, A. Witko, 101 pytań o Boże Miłosierdzie, Kraków 2006; w zakresie liturgiki: A. Mojżeszko, Idea miłosierdzia Bożego w Mszale Rzymskim Pawła VI, Kraków 2000; w zakresie patrologii: R. Świder, Nauka św. Augustyna 


\section{Zakończenie}

Głównym motywem napisania tego artykułu jest przybliżenie możliwie jak największej liczbie ludzi bogactwa myśli wybitnej postaci, ale trochę zapomnianej, św. biskupa z Arles (470-543). Episkopat Francji w roku 2017 wystosował prośbę do Watykanu o rozszerzenie kultu św. Cezarego z Arles na cały Kościół powszechny. Być może zostanie on nawet w niedalekiej przyszłości ogłoszony doktorem Kościoła. Ze względu na wielkie walory świadectwa życia biskupa z Arles i aktualność jego nauczania, dobrze by było dedykować temu świętemu kościół, albo kaplice. Rzeczą naturalną będzie dokończenie przygotowania tekstu krytycznego, nad czym pracuje zespół naukowców związanych z serią wydawniczą Sources Chrétiennes ${ }^{55}$ : "Sermons 106 à 238+10" = 248 (3 tomes); "Correspondances de Césaire d'Arles”; 2 traités théologiques (sur la Grâce, la Trinité); „1 traité théologique sur l“Apocalypse”; „2 Bréviaires, un bréviaire contre les hérétiques et un bréviaire contre les ariens". Z wymienionych wyżej pozycji mamy już w języku polskim: „2 traités théologiques” - O łasce, o Trójcy Świętej; „1 traité théologique sur l'Apocalypse” - Objaśnienie Apokalipsy św. Jana; „un bréviaire contre les hérétiques” - Krótkie wyznanie wiary przeciwko heretykom. Powoli finalizuję przekład i opracowanie Kazań 81-105, pozostaną do przetłumaczenia jeszcze Kazania 106-232 (81-186 o Piśmie Świętym - częściowo przełożone; 187-213 na poszczególne święta - częściowo przełożone; 214-232 kazania o świętych - częściowo przełożone), na których krytyczny tekst trzeba zaczekać oraz Mowy do mnichów (233-238) ${ }^{56}$.

Św. Cezary z Arles, genialny biskup i kaznodzieja ze względu na swe osobiste - niezwykle głębokie - świadectwo o Chrystusie, w dobie wielkich przemian w Europie na przełomie V/VI wieku, może być wzorem do naśladowania dla chrześcijan w każdym miejscu i czasie.

o miłosierdziu Boga w „Objaśnieniach Psalmów”, Kraków 1989 (pr. lic.); L. Mateja, Oblicza miłosierdzia. Historyczne uwarunkowania rozwoju doktryny o miłosierdziu. Studium dzieł Tertuliana i św. Cypriana, Kraków 2003; J. Pochwat MS, Sprawiedliwość i miłosierdzie, dz. cyt., Kraków 2008.

55 Césaire d'Arles et les cinq continents, Éditeur: Aux sources de la Provence, t. I-IV, Venelles 2017-2020.

56 Cezary z Arles, Mowy do mnichów, tłum. J. Piłat, w: Cezary z Arles, Pisma monastyczne, opr. i red. M. Starowieyski, Kraków 1994, s. 97-132 (Źródła Monastyczne, 2). 


\section{Summary}

Wybrane aspekty z przepowiadania św. Cezarego z Arles.

Czy św. Cezary z Arles będzie nowym doktorem Kościoła?

Święty Cezary z Arles (470-543) wielki kaznodzieja, duszpasterz, organizator życia kościelnego i monastycznego w Galii, pozostawił po sobie dzieła, których aktualność nie straciła swych walorów do dnia dzisiejszego. Znany jest na 5 kontynentach świata w 38 krajach, bardziej w ośrodkach naukowych niż wśród „zwykłych wiernych. Jego spuścizna literacka doczekała się wielu opracowań, gdzie środowisko polskich patrologów, może poszczycić się bogatą literaturą. Osoba biskupa Arles, jak i jego nauczanie jest godne uwagi, a praktyczne wskazania Cezarego mogą pomóc w rozwiązywaniu trudnych kwestii życia współczesnych chrześcijan.

Słowa kluczowe: sprawiedliwość, miłosierdzie, eschatologia, społeczeństwo, modlitwa, Msza święta, chrzest

Selected aspects from the preaching of St Caesarius of Arles.

Is St Caesarius of Arles to be the new doctor of the Church?

St. Caesarius of Arles (470-543) a great preacher, pastor, organizer of church and monastic life in Gaul, left behind works, which are still of importance to us today. He is known on 5 continents of the world in 38 countries, more in research centers than among "ordinary" faithful. His literary heritage has been elaborated and studied much, where the Polish patrologists, have contributed greatly to it. The Bishop of Arles and his teaching is remarkable, and his practical suggestions can help in solving difficult life problems of modern Christians.

Keywords: justice, mercy, eschatology, society, prayer, Holy Mass, baptism

\section{Bibliografia}

\section{Źródła}

Césaire a'Arles, Sermons au peuple, introductions, traduction et notes par M.-J. Delage, t. 1, Sources Chrétiennes 175, Paris 1971

Césaire a'Arles, Sermons au peuple, introductions, traduction et notes par M.-J. Delage, t. 2, Sources Chrétiennes 243, Paris 1978.

Césaire a'Arles, Sermons au peuple, introductions, traduction et notes par M.-J. Delage, t. 3, Sources Chrétiennes 330, Paris 1986. 


\section{Opracowania}

Altaner B., Stuiber A., Patrologia, przeł. P. Pachciarek, Warszawa 1990, s. 618-619.

Banaszak M., Weiss A., Arles, w: Encyklopedia katolicka, t. 1, red. E. Gigilewicz, Lublin 1989, s. 926.

Bihlmeyer K.-Tüchle H., Historia Kościoła, t. 1, tłum. J. Klenowski, Warszawa 1971.

Bober A., Antologia patrystyczna, Kraków 1965.

Bober A., Miłosierdzie Boże w wypowiedziach Ojców Kościoła. w: Powołanie człowieka, t. 2, Poznań 1972, s. 41.

Césaire d'Arles et les cinq continents, Éditeur: Aux sources de la Provence, t. I-IV, Venelles 2017-2020.

Cezary z Arles, Pisma dogmatyczne i egzegetyczne, przeł. A. Strzelecka, opr. P. Wygralak, Poznań 2004 (POK, 29).

Cezary z Arles, Homilie do Księgi Rodzaju. Objaśnienie Apokalipsy św. Jana, oprac. A. Żurek, Kraków 2002 (BOK, 17).

Chadwick H., Kościół w epoce wczesnego chrześcijaństwa, tłum. A. Wypustek, Warszawa 2004.

Cyprian, Firmin, Wiwencjusz, Messjan, Stefan, Żywot Cezarego z Arles, przeł. A. Strzelecka, opr. P. Wygralak, Poznań 2008 (POK, 32).

Cytowska M., Szelest H., Literatura Rzymska. Okres cesarstwa. Autorzy chrześcijańscy, Warszawa 1994.

Św. Cezary z Arles, oprac. i wybór tekstów A. Żurek, Kraków 2002 (Ojcowie Żywi, 17).

Św. Cezary z Arles, Homilie do Księgi Rodzaju, Objaśnienie Apokalipsy św. Jana, przeł., wstępem opatrzył i opr., A. Żurek, Kraków 2002 (BOK, 17).

Daniélou J., Marrou H.-I., Historia Kościoła, tłum. M. Tarnowska, t. 1, Warszawa 1984.

Durlak L., Miłość zasada życia chrześcijańskiego. Studium kazań Cezarego z Arles, Kraków 1998 (pr. lic.).

Eckmann A., Grzech pierworodny jako źródło cierpień człowieka u św. Augustyna, w: Grzech pierworodny, Kraków 1999, s. 109-125, szczególnie s. 116 (ŹMT, 12).

Fontaine J., La littérature latine chretiénne, Paris 1970.

Fontaine J., Chrześcijańska literatura łacińska. Rys historyczny, tłum. J. Słomka, Tarnów 1997.

Gładyszewski L., Cezary z Arles, w: Encyklopedia katolicka, t. 3, red. E. Gigilewicz, Lublin 1989, s. 42-44.

Grzywaczewski J., Pogłębianie wiedzy religijnej jako obowiązek chrześcijanina według Cezarego z Arles, „Roczniki Humanistyczne” 44 (1996) nr 3, s. 249-260.

Grzywaczewski J., Formacja permanentna duchowieństwa według św. Cezarego z Arles, w: Droga doskonalenia chrześcijańskiego w epoce patrystycznej, red. F. Drączkowski, J. Pałucki, M. Szram, Lublin 1997, s. 151-168.

Grzywaczewski J., La lecture à la campagne en Gaule au VIe siècle d'après les Sermons de Césaire d'Arles, VoxP 22 (2002), nr 42-43, s. 463-474. 
Grzywaczewski J., The Biblical Idea of Divine Mercy in the Early Church, Warszawa 2016, s. 308-321.

Jaśkiewicz G., Problematyka moralna w kaznodziejstwie Cezarego z Arles, „Wrocławski Przegląd Teologiczny" 29 (2012), s. 97-107.

Kołosowski T., Przepowiadanie wiary $w$ środowisku wiejskim $w$ kazaniach św. Cezarego $z$ Arles, w: Ewangelizacja w epoce patrystycznej, red. F. Drączkowski, J. Pałucki, Lublin 1994, s. 39-60.

Kołosowski T., Nauczanie biskupa Cezarego z Arles na temat kultu świętych w kontekście ówczesnej religijności chrześcijańskiej, „,Saeculum Christianum” 6 (1999), nr 2, s. 5-16.

Kołosowski T., Nauka o szatanie, jego oddziaływaniu na ludzi i walce z nim, w kazaniach św. Cezarego z Arles, w: Demonologia w nauce Ojców Kościoła, red. H. Pietras, Kraków 2000, s. 99-108 (ŹMT, 17).

Kumor B., Historia Kościoła, t. 1, Lublin 2001.

Machniak J., Doświadczenie Boga w tajemnicy Jego Miłosierdzia u bł. Siostry Faustyny Kowalskiej, Kraków 1999.

Marrou H.-I., Zmierzch Rzymu czy późna starożytność? III -VI wiek, tłum. M. Węcowski, Warszawa 1997.

Mateja L., Oblicza miłosierdzia. Historyczne uwarunkowania rozwoju doktryny o mitosierdziu. Studium dzieł Tertuliana i św. Cypriana, Kraków 2003.

Mojżeszko A., Idea miłosierdzia Bożego w Mszale Rzymskim Pawła VI, Kraków 2000.

Mowy do Mnichów 233-238, przeł. J. Piłat, w: Cezary z Arles, Pisma monastyczne, opr. i red. M. Starowieyski, Tyniec 1994, s. 97-132 (Źródła Monastyczne, 2).

Pietras H., Dzień święty, Kraków 1992.

Piłat J., Św. Cezary z Arles (†543). Bibliografia - aktualny stan badań, w: Oblicza doskonałości chrześcijańskiej, red. M. Chmielewski, Lublin 1996, s. 206-218.

Pochwat J., Sprawiedliwość i miłosierdzie. Studium „Kazań do ludu” św. Cezarego z Arles, Kraków 2008.

Pochwat J., Obraz społeczeństwa Galii pierwszej połowy VI wieku. Studium „Kazań do ludu" św. Cezarego z Arles, w: Fructus Spiritus est Caritas: Ksiegga jubileuszowa ofiarowana Księdzu Profesorowi Franciszkowi Draczkowskiemu z okazji siedemdziesiątej rocznicy urodzin, czterdziestopięciolecia święceń kapłańskich i trzydziestopięciolecia pracy naukowej, red. M. Wysocki, Lublin 2011.

Pochwat J., Św. Cezary z Arles ijego czasy, w: Św. Cezary z Arles, Kazania do ludu (1-80), tłum. S. Ryznar CSsR (1-55), J. Pochwat MS (56-80), Kraków 2011, s. 5-21, bibliografia s. 23-32 (ŹMT, 57).

Pochwat J., Św. Cezary z Arles, jako nauczyciel modlitwy, na podstawie jego „Kazań do ludu", w: Przez Maryję ku Wcielonemu Słowu, red. J. Kręcidło, Kraków 2012, s. 73-97 (Studia Salettensia, 5).

Pochwat J., Dzień Pański w nauczaniu św. Cezarego z Arles wświetle jego „Kazań do ludu”, VoxP 33/60 (2013), s. 245-262.

Pochwat J., Konsekwencje chrztu według św. Cezarego z Arles, w: Chrzest w teologicznej refleksji Ojców Kościoła, Poznań 2016, s. 77-94 (TPatr, 13). 
Pochwat J., Specyfika głównych ośrodków życia monastycznego w Galii w IV $i$ V wieku, „Polonia Sacra” 21 (2017) nr 3 (48), s. 107-128.

Pochwat J., Sprawiedliwość Boga wobec Szatana na podstawie jedenastego kazania do ludu św. Cezarego z Arles, „Polonia Sacra” 21 (2017) nr 4 (49), s. 167-185.

Riché P., Edukacja i kultura w Europie Zachodniej (VI-VIII w.), tłum. M. Radożycka-Paoletti, Warszawa 1995.

Riché P., Education et culture dans l'occident barbare (VIe - VIIIe siècles), Paris 1962.

Stanula E., Wstęp, w: Św. Cezary z Arles, Kazania, tłum. S. Ryznar, Warszawa 1989, s. 5-15 (PSP, 52).

Starowieyski M., Ze świata wczesnego chrześcijaństwa, Pelplin 1998.

Szymusiak J. M., Patrologia. Zagadnienia wybrane, Lublin 1971.

Szweda P., Witko A., 101 pytań o Boże Miłosierdzie, Kraków 2006.

Śrutwa J., Galia, w: Encyklopedia katolicka, t. 5, Lublin 1989, s. 818-819.

Świder R., Nauka św. Augustyna o miłosierdziu Boga w „Objaśnieniach Psalmów”, Kraków 1989 (pr. lic.).

Wiszniewski R., Zadania biskupa w świetle „Kazañ” św. Cezarego z Arles, VoxP 13-15 (1993-1995) nr 24-29, s. 181-202.

Wygralak P., Praktyki pokutne w nauczaniu św. Cezarego z Arles, „Poznańskie Studia Teologiczne" 8 (1998), s. 99-108.

Wygralak P., Grzech pierworodny w kaznodziejskim nauczaniu św. Cezarego z Arles (†542), w: Grzech pierworodny, tłum. ks. K. Obrycki, Kraków 1999, s. 131-140 (ŹMT, 12).

Wygralak P., Dobroć Boga Ojca w nauczaniu św. Cezarego z Arles, „Studia Aniquitatis Christianae" 15 (2001), 109-116.

Wygralak P., Cezarego z Arles wybrane kazania o pokucie i Bożym Miłosierdziu,, 2004, s. 115-119 (TPatr, 1).

Wygralak P., Praktyki pokutne w nauczaniu św. Cezarego z Arles, „Poznańskie Studia Teologiczne" 8 (1998), s. 104-105.

Żurek A., Wprowadzenie do Ojców Kościoła, Tarnów 1998.

Żurek A., Pierwsze wieki Kościoła (I-VII), Tarnów 2000.

Żurek A., Cezary z Arles, Kraków 2003 (Wielcy Ludzie Kościoła).

Żurek A., Il matrimonio nei Sermoni di Cesario di Arles, Roma 1985.

Żurek A., Małżeństwo i prokreacja według Cezarego z Arles, VoxP 7 (1987) nr 12-13, s. $427-440$.

Żurek A., Katecheza Cezarego z Arles, VoxP 10 (1990), nr 18, s. 147-156.

Żurek A., La carità cristiana nella Gallia della fine del V e prima metà del VI secolo, ,Studia Ephemeridis Augustinianum" 46 (1994), s. 567-572.

Żurek A., Formacja intelektualno-ascetyczna duchowieństwa $w$ V-VI wieku $w$ Galii na podstawie pism św. Cezarego z Arles, VoxP 13-15 (1993-1995) nr 24-29, s. 173-180.

Żurek A., Wpływ św. Cezarego († 542/3 r.) na życie i ksztalt miasta Arles, w: Sympozja Kazimierskie poświęcone kulturze świata późnego antyku i wczesnego chrześcijaństwa, red. B. Iwaszkiewicz-Wronikowska, D. Próchniak, t. 3, Lublin 2002, s. 77-87. 